\title{
PEMAHAMAN IBU HAMIL TENTANG UPAYA PENCEGAHAN INFEKSI COVID-19 SELAMA KEHAMILAN
}

\section{UNDERSTANDING OF PREGNANT WOMEN ABOUT EFFORTS TO PREVENT COVID-19 INFECTION DURING PREGNANCY}

\author{
Ronni Naudur Siregar ${ }^{1}$, Juneris Aritonang ${ }^{* 2}$, Surya Anita ${ }^{3}$ \\ 1,2,3 Universitas Sari Mutiara Indonesia, Jl. Kapten Muslim No 79 Medan, Sumatera Utara, 20123, Indonesia \\ *Koresponding Penulis: onisiregar62@gmail.com ${ }^{1}$, june_30ops@yahoo.co.id ${ }^{* 2}$, surya.anita79@yahoo.co.id ${ }^{3}$
}

\begin{abstract}
Abstrak
Indonesia merupakan salah satu negara yang terjangkit pandemi Corona Virus Disease19 (COVID-19) dengan angka kejadian terkonfirmasi (kasus baru) yang bertambah secara fluktuatif. Situasi pandemi COVID-19 ini memerlukan pemahaman dalam upaya pencegahan infeksi COVID-19. Jenis penelitian adalah kuantitatif dengan desain deskriptif . data yang diperoleh melalui kuesioner kepada ibu hamil sebagai sample yang berkunjung pada saat penelitian berlangsung (accidental sampling). Dari hasil penelitian didapati mayoritas responden (57\%) memiliki pemahaman yang kurang tentang upaya pencegahan infeksi COVID-19. Perlu dilakukan upaya untuk peningkatan pemahaman ibu hamil upaya pencegahan penularan COVID19 agar dapat menekan jumlah kasus yang kian meningkat.
\end{abstract}

\section{Kata Kunci : Pemahaman, ibu hamil, pencegahan COVID-19}

\begin{abstract}
Indonesia is one of the countries affected by the Corona Virus Disease-19 (COVID-19) pandemic with a fluctuating increase in the number of confirmed incidents (new cases). This COVID-19 pandemic situation requires understanding in efforts to prevent COVID-19 infection. This type of research is quantitative with a descriptive design. Data obtained through questionnaires to pregnant women as a sample who visited during the study (accidental sampling). From the research results, it was found that the majority of respondents (57\%) had a lack of understanding of efforts to prevent COVID-19 infection. Efforts need to be made to increase understanding of pregnant women to prevent the transmission of COVID-19 in order to reduce the increasing number of cases
\end{abstract}

Keywords: Understanding, pregnant women, prevention of COVID-19 
Journal of Healthcare Technology and Medicine Vol. 6 No. 2 Oktober 2020

Universitas Ubudiyah Indonesia

e-ISSN : 2615-109X

\section{PENDAHULUAN}

Indonesia merupakan salah satu negara yang terjangkit pandemi Corona Virus Disease19 (COVID-19) dengan angka kejadian terkonfirmasi COVID-19 (kasus baru) yang bertambah secara fluktuatif (Purnamasari \& Raharyani, 2020). COVID-19 pertama sekali diumumkan oleh World Health Organization (WHO) pada akhir tahun 2019 sebagai penyakit menular yang disebabkan Virus Corona (Virus SARS-COV 2) (Zhong et al., 2020). Awalnya, COVID-19 dilaporkan mayoritas menyerang kelompok lanjut usia, namun, belakangan ini dilaporkan juga telah menyerang seluruh kelompok usia (bayi, balita, remaja, usia produktif, dan kelompok ibu hamil). Tercatat di kabupaten Banyumas (April 2020) terdapat 2 ibu hamil (usia 26 dan 31 tahun) meninggal dunia yang merupakan kelompok PDP (Artathi Eka Suryandari \& Trisnawati, 2020).

Terjadinya perubahan fisiologis pada masa kehamilan mengakibatkan kekebalan parsial menurun sehinnga dapat berdampak serius pada ibu hamil, hal inilah penyebab ibu hamil dijadikan kelompok rentan resiko terinfeksi COVID-19 (Liang \& Acharya, 2020). Belum dapat dipastikan adanya penularan vertikal pada masas hamil, hal ini dibuktikan dengan hasil penelitian didapati $37 \mathrm{ibu}$ hamil yang terkonfirmasi COVID-19 tidak ditemukan adanya kematian maternal dan 30 neonatus yang dilahirkan tidah ditemukannya adanya yang terkonfirmasi COVID-19 (Schwartz, 2020).

Situasi pandemi COVID-19 ini meningkatkan kecemasan ibu hamil, bukan saja mencemaskan keadaan janinnya tetapi juga mencemaskan apakah ibu dan janin akan sehat bebas infeksi COVID-19, aman atau tidaknya dalam pemeriksaan kehamilan selama pandemi. Pemerintah dan berbagai lembaga telah melakukan upaya-upaya berupa sosialisasi mengenai COVID-19 termasuk pencegahan penularan COVID-19 tetapi masih banyak masyarakat yang belum memahaminya. Terjadinya keadaan tersebut dikarenakan informasi palsu (hoax) yang banyak beredar di masyarakat (Saputra, 2020). Kehamilan yang disertai dengan kecemasan akan menurunkan imun ibu sehingga ibu hamil akan semakin rentan terinfeksi COVID-19.

Penelitian ini dilakukan di Balai Pengobatan Swasta Mariana yang terletak di Kabupaten Deliserdang. Didapati jumlah terkonfirmasi COVID-19 di kabupaten ini pada tanggal 30 Agustus 2020 berjumlah 861 kasus (SUMUT, 2020). Surei awal ditemukan banyaknya ibu hamil tidak 
Journal of Healthcare Technology and Medicine Vol. 6 No. 2 Oktober 2020

Universitas Ubudiyah Indonesia

e-ISSN : 2615-109X

memakai masker pada saat beraktivitas di luar rumah. Bukan hanya tidak menggunakan masker saja, ditemukan juga ibu hamil bersama tertangganya berbincang-bincang tanpa melaksanakan protokol kesehatan yang tepat seperti memakai masker, menjaga jarak dan menghindari kerumunan. Wawancara awal juga dilakukan kepada ibu hamil yang datang berkunjung ke Balai Pengobatan Swasta Mariana berjumlah 7 orang. Seluruh ibu hamil tersebut mengaku merasakan cemas dalam menjalani kehamilan di masa pandemi COVID-19.

Dua orang ibu hamil merasa takut pada saat melakukan pemeriksaan kehamilan di pelayanan kesehatan. Terdapat dua orang ibu hamil yang tidak memakai masker pada saat berkunjung ke Balai Pengobatan Swasta Mariana, dan bidan yang bertugas memberikan masker kepada ibu dan pendamping sebelum masuk ke klinik dan menjalankan pemeriksaan kehamilan. Tiga ibu hamil memakai masker tetapi tidak memakai dengan tepat. Ada perbedaan antara kecemasan yang disampaikan oleh ibu hamil dengan upaya pencegahan tertularnya COVID-19 yang dilakukan ibu hamil. Dari latar belakang yang telah diuraikan penulis tertarik melakukan penelitian dengan judul "Pemahaman Ibu Hamil Tentang Upaya Pencegahan Infeksi COVID-19 Selama Kehamilan" penelitian ini belum pernah dilakukan sebelumnya, dan sangat penting dilakukan untuk lebih menemukan cara yang tepat nantinya untuk memberikan upaya-upaya dalam pencegahan COVID-19 pada masyarakat umumnya dan ibu hamil khususnya.

\section{METODE PENELITIAN}

Jenis penelitian adalah penelitian kuantitatif menggunakan desain penelitian deskriptif untuk melihat gambaran tingkat pemahanan ibu hamil tentang upaya pencegahan infeksi COVID-19 selama kehamilan. Lokasi penelitian di Balai Pengobatan Swasta Mariana dengan populasi adalah seluruh ibu hamil yang datang berkunjung ke Balai Pengobatan Swasta Mariana selama masa pandemi COVID-19 (Maret-Agustus 2020) pengambilan sampel menggunakan accidental sampling, seluruh ibu hamil dijadikan sampel pada saat penelitian berlangsung (14 Agustus-30 Agustus 2020) dan bersedia dijadikan responden penelitian yakni berjumlah 37 orang. Pengumpulan data dengan menggunakan kuesioner dan data yang diperoleh dianalisa dengan secara univariat. 


\section{HASIL DAN PEMBAHASAN}

1. Karakteristik responden berdasarkan usia, pendidikan, pekerjaan, dan status kehamilan

Tabel 1. Distribusi frekuensi karakteristik responden berdasarkan usia, pendidikan, pekerjaan, dan usia kehamilan

\begin{tabular}{|c|c|c|c|}
\hline No & Karakteristik & Jumlah & Persentas (\%) \\
\hline \multirow[t]{4}{*}{1.} & Usia & & \\
\hline & $<20$ tahun & 8 & 21.6 \\
\hline & $20-35$ ahun & 24 & 64.9 \\
\hline & $>35$ tahun & 5 & 13.5 \\
\hline \multicolumn{2}{|c|}{ Total } & 37 & 100 \\
\hline \multirow[t]{5}{*}{2} & Pendidikan & & \\
\hline & SD & 6 & 16 \\
\hline & SMP & 10 & 27 \\
\hline & SMA & 13 & 35 \\
\hline & Perguruan tinggi & 8 & 22 \\
\hline \multicolumn{2}{|c|}{ Total } & 37 & \\
\hline \multirow[t]{5}{*}{3} & Pekerjaan & & \\
\hline & Ibu Rumah Tangga (IRT) & 18 & 48.6 \\
\hline & PNS & 7 & 19 \\
\hline & Pegawai Swasta & 6 & 16.2 \\
\hline & Buruh & 6 & 16.2 \\
\hline \multicolumn{2}{|c|}{ Total } & 37 & 100 \\
\hline \multirow[t]{4}{*}{4} & Usia kehamilan & & \\
\hline & Trimester I & 9 & 24 \\
\hline & Trimester II & 15 & 41 \\
\hline & Trimester III & 13 & 35 \\
\hline Total & & 37 & 100 \\
\hline
\end{tabular}

Dari tabel 1 didapati mayoritas responden berada di kelompok usia 20-35 tahun (64.9\%). Usia muda lebih tinggi memiliki kemampuan berkreatifitas, mencari informasi, daya ingat dibandingkan usia yang lebih tua. Pada kelompok usia muda lebih maksimal menyerap informasi baru dibandingkan kelompok usia lebih tua (Maramis et al., 2013). Bertambahnya usia seseorang semakin menambah pengetahuan yang dipunyainya (Corneles \& Losu, 2015).

Mayoritas responden berpendidikan SMA sebesar 35\%, hanya $22 \%$ (8 responden) saja tingkat pendidikan hingga ke perguruan tinggi. Tingkat pendidikan berpengaruh juga pada daya tanggap dam memahami suatu informasi baru. Tingkat penerimaan seseorang akan lebih mudah 
Journal of Healthcare Technology and Medicine Vol. 6 No. 2 Oktober 2020

Universitas Ubudiyah Indonesia

e-ISSN : 2615-109X

pada seseorang dengan pendidikan tinggi dari pada pendidikan menengah terlebih rendah (Corneles \& Losu, 2015). Mairusnita, 2007 dalam (Maramis et al., 2013) mengatakan pendidikan berbanding lurus dengan tingkat pemahaman terhadap suatu informasi, yang artinya semakin tinggi tingkat pendidikan seseorang maka semakin tinggi juga tingkat pengetahuan seseorang dan ketepatan dalam bersikap dan berperilaku, maka pendidikan memiliki pengaruh yang besar pada aspek pikiran, sikap, kemauan, dan tindakan.

Hasil penelitian juga ditemukan mayoritas responden adalah ibu rumah tangga (48.6\%). (Nursalam, 2012) mengatakan pekerjaan bukan saja sebagai sumber nafkah bagi kelangsungan kehidupan melainkan secara btidak langsung sebagai media penyerapan informasi yang terbaru dari lingkungan kerja.

\section{Pemahanan ibu hamil tentang upaya pencegahan infeksi COVID-19 selama kehamilan}

Tabel 2. Distribusi frekuensi Pemahanan ibu hamil tentang upaya pencegahan infeksi COVID-19 selama kehamilan

\begin{tabular}{crccc}
\hline No & & Pengetahuan & Jumlah & Persentas (\%) \\
\hline \multirow{2}{*}{1} & Kurang & 21 & 57 \\
\cline { 2 - 5 } \multicolumn{1}{c}{ Baik } & & 16 & 43 \\
\hline \multicolumn{2}{c}{ Total } & & $\mathbf{3 7}$ & $\mathbf{1 0 0}$ \\
\hline
\end{tabular}

Hasil penelitian yang dapat dilihat dari tabel 2 didapati bahwa mayoritas responden memiliki pengetahuan yang kurang tentang upaya pencegahan infeksi COVID-19 selama kehamilan. Kurangnya pengetahuan ibu hamil tentang upaya pencegahan infeksi COVID-19 selama kehamilan dapat disebabkan dari factor karekteristik responden dimana mayoritas responden berada di tingkat pendidikan menengah sehingga sangat sulit menerima informasi yang baru, selain itu didukung pula dengan responden mayoritas sebagai ibu rumah tangga, yang memiliki pengalaman penerimaan informasi hanya dari anggota keluarga serumah, dan tetangga. Hal ini memberikan akses yang terbatas dalam penerimaan informasi terbaru. Dibandingan dengan seseorang yang bekerja di luar rumah seperti buruh, kantor, dll memiliki peluang informasi yang terbaru dan adanya diskusi mengenai informasi tersebut.

Berbagai upaya termasuk sosialisasi yang telah dilakukan untuk pencegahan infeksi COVID-19 melalui media social, media massa baik cetak maupun elektronik, brosur, spanduk di 
Journal of Healthcare Technology and Medicine Vol. 6 No. 2 Oktober 2020

Universitas Ubudiyah Indonesia

e-ISSN : 2615-109X

setiap sudut kota, dipabrik maupun di kantoran (Tim COVID-19 IDAI, 2020). Jika dibandingkan antara seseorang dalam kesehariannya sebagai ibu rumah tangga hanya memperoleh informasi dari media social dan media massa baik cetak maupun elektronik. Pada kelompok ibu yang bekerja di luar rumah memiliki akses luas ditambah lagi adanya protokol-protokol yang harus dipatuhi ketika di tempat kerjaan termasuk pada ibu hamil.

Rendahnya pemahanan ibu hamil tentag upaya pencegahan infeksi COVID-19 selama kehamilan dikarenakan masih beredarnya informasi-informasi palsu di masyarakat luas mengenai COVID-19 termasuk penularan, pengobatan dan pencegahan tertularnya COVID-19 (Saputra, 2020).

Melalui (Kementrian Kesehatan Republik Indonesia, 2020) dikatakan bahwa pada kelompok ibu hamil, ibu nifas, ibu memiliki bayi, ibu menyusui dalam upaya pencegahan infeksi COVID-19 memiliki prinsip universal precaution seperti mencuci tangan memakai sabun dan air mengalir sesering mungkin selama 20-60 detik atau jika tidak ada dapat menggunakan hand sanitizer, menjaga jarak dan menghindari kerumunan, memakai alat pelindung diri (masker), mempraktikkan etika batuk bersin, menjaga kebugaran tubuh dan menjaga kestabilitasan imun tubuh.

Item kuesioner yang diberikan, mayoritas responden sudah memahami etika batuk yang tepat (60\%). Pemakaian alat pelindung diri mayoritas responden berpengetahuan kurang (78\%), responden belum memahami bagaimana cara pemakaian, pelepasan masker yang tepat, pemilihan masker yang baik, dan pergantian masker yang dianjurkan selama pandemi COVID19. Selain itu, dari kuesioner yang diberikan mayoritas responden belum memahami protokol keluar dan sesampai dari rumah. Hanya 38\% responden yang memahami langkah yang dilakukan responden sesampai di rumah setelah bepergian dari rumah. Pada item pencegahan COVID-19 didapati mayoritas (42\%) responden kurang memahami prosedur sebelum melakukan pemeriksaan kehamilan. (Kementrian Kesehatan Republik Indonesia, 2020) melalui Pedoman Bagi IbuHamil, , Ibu Nifas dan bayi Baru Lahir dikatakan pada ibu hamil untuk pemeriksaan hamil pertama kali, terlebih dahulu membuat janji dengan bidan ataupun dokter. Hal ini dilakukan sebagai upaya pencegahan terinfeksi COVID-19, agar ibu hamil tidak lama menunggu antrian pada saat sebelum pemeriksaan kehamilan. Landasan penting dalam suatu tindakan dan 
Journal of Healthcare Technology and Medicine Vol. 6 No. 2 Oktober 2020

Universitas Ubudiyah Indonesia

e-ISSN : 2615-109X

pengambilan keputusan adalah sebuah pengetahuan. Seseorang berpengetahuan baik akan menerapkan pengetahuannya di dalam kehidupannya sehari-hari (Aritonang, 2018; Bancin et al., 2020). Hal ini sesuai dengan penelitian yang dilakukan (Purnamasari \& Raharyani, 2020) terdapat hubungan yang bermakna antara pengetahuan masyarakat terhadap perliku tentang COVID-19.

Menurut asumsi penulis, dalam upaya pencegahan penularan COVID-19 perlu dilakukan peningkatan pemahaman masyarakat secara umum khususnya ibu hamil upaya pencegahan penularan COVID-19 agar dapat menekan jumlah kasus yang kian meningkat.

\section{KESIMPULAN}

Hasil penelitian didapati bahwa mayoritas responden memiliki pengetahuan yang kurang tentang upaya pencegahan infeksi COVID-19 selama kehamilan.

\section{SARAN}

Perlu dilakukan upaya untuk peningkatan pemahaman masyarakat secara umum khususnya ibu hamil upaya pencegahan penularan COVID-19 agar dapat menekan jumlah kasus yang kian meningkat.

\section{DAFTAR PUSTAKA}

Aritonang, J. (2018). Peningkatan Pengetahuan Ibu Tentang Imunisasi Pentabio Lanjutan Setelah Pemberian Pendidikan Kesehatan Di Puskesmas Lampaseh Aceh. Jurnal Riset Kesehatan Nasional. https://doi.org/10.37294/jrkn.v2i2.125

Artathi Eka Suryandari, \& Trisnawati, Y. (2020). Studi Deskriptif Perilaku Bidan Dalam Penggunaan Apd Saat Pertolongan Persalinan Selama Pandemi COVID-19. Jurnal Bina Cipta Husada, 4(2), 119-128. https://stikesbinaciptahusada.ac.id/filejurnalbch/index.php/filejurnalbch/article/view/38

Bancin, D. R., Anita, S., \& Aritonang, J. (2020). Faktor-Faktor Yang Berhubungan Dengan Pemakaian Kondom Pada Wanita Pekerja Seksual (Wps) Di Wilayah Kerja Puskesmas Bandarbaru Kecamatan Sibolangit Tahun 2020. In Jurnal Kesehatan Al-Irsyad. https://doi.org/10.1017/CBO9781107415324.004

Corneles, S., \& Losu, F. (2015). Hubungan Tingkat Pendidikan Dengan Pengetahuan Ibu Hamil Tentang Kehamilan Risiko Tinggi. Jurnal Ilmiah Bidan.

Kementrian Kesehatan Republik Indonesia. (2020). Pedoman Bagi Ibu Hamil, Ibu Nifas, dan Bayi Baru Lahir Di Era Pandemi Covid-19Kementrian Kesehatan Republik Indonesia. In Kementrian Kesehatan Republik Indonesia (Revisi 1). Kementerian Kesehatan RI. http://www.kesga.kemkes.go.id/images/pedoman/Pedoman bagi Ibu Hamil, Bersalin, Nifas 
dan BBL di Era Pandemi COVID 19.pdf

Liang, H., \& Acharya, G. (2020). Novel corona virus disease (COVID-19) in pregnancy: What clinical recommendations to follow? Acta Obstetricia et Gynecologica Scandinavica. https://doi.org/10.1111/aogs.13836

Maramis, P., Ismanto, A., \& Babakal, A. (2013). Hubungan Tingkat Pendidikan Dan Pengetahuan Ibu Tentang Ispa Dengan Kemampuan Ibu Merawat Balita Ispa Pada Balita Di Puskesmas Bahu Kota Manado. Jurnal Keperawatan UNSRAT.

Nursalam. (2012). Metodologi Penelitian Ilmu Keperawatan. In Jakarta: Salemba Merdeka.

Pradana, A. A., Casman, C., \& Nur'aini, N. (2020). Pengaruh Kebijakan Social Distancing pada Wabah COVID-19 terhadap Kelompok Rentan di Indonesia. Jurnal Kebijakan Kesehatan Indonesia : JKKI, 09(02), 61-67. https://doi.org/10.22146/JKKI.55575

Purnamasari, I., \& Raharyani, A. E. (2020). Tingkat Pengetahuan dan Perilaku Masyarakat Kabupaten Wonosobo Tentang Covid-19. Jurnal Ilmiah Kesehatan, 10(1), 33-42. https://ojs.unsiq.ac.id/index.php/jik/article/view/1311

Saputra, D. (2020). Fenomena Informasi Palsu ( Hoax ) Pada Media Sosial di Tengah Pandemi Covid-19 dalam Perspektif Islam Devid Saputra. Mau'idhoh Hasanah: Jurnal Dakwah Dan Ilmu Komunikasi, 2(1), 1-10. http://journal.iaiagussalimmetro.ac.id/index.php/mauidhohhasanah/article/view/69/40

Schwartz, D. A. (2020). An analysis of 38 pregnant women with COVID-19, their newborn infants, and maternal-fetal transmission of SARS-CoV-2: Maternal coronavirus infections and pregnancy outcomes. Archives of Pathology and Laboratory Medicine. https://doi.org/10.5858/arpa.2020-0901-SA

SUMUT, C.-19. (2020). No Title. Update Data Kasus COVID-19 Di SUmatera Utara, Jumat 28 Agustus 2020. http://covid19.sumutprov.go.id/article/title/update-data-kasus-covid19-disumatera-utara-28-Agustus-2020

Tim COVID-19 IDAI. (2020). Protokol Tatalaksana Covid-19. 1.

Zhong, B. L., Luo, W., Li, H. M., Zhang, Q. Q., Liu, X. G., Li, W. T., \& Li, Y. (2020). Knowledge, attitudes, and practices towards COVID-19 among chinese residents during the rapid rise period of the COVID-19 outbreak: A quick online cross-sectional survey. International Journal of Biological Sciences. https://doi.org/10.7150/ijbs.45221 